\title{
DEVELOPING STUDENTS' SPEAKING WORKSHEET BASED ON \\ SCIENTIFIC APPROAH FOR GRADE X \\ SENIOR HIGH SCHOOL TELADAN MEDAN
}

\author{
*Inriwati Saragih \\ ** Masitowarni Siregar \\ **Nora Ronita Dewi
}

\begin{abstract}
Saragih, Inriwati. Registration Number: 2142121008. Developing Students' Speaking Worksheet based on Scientific Approach for Grade X Senior High School Teladan Medan.A Thesis. English Education Program, State University of Medan, 2018.

The objective of this research was to develop the appropriate English speaking worksheet based on scientific approach for grade X of Senior High School students. This research belongs to Research and Development (R\&D) study through seven phases; gathering information and data, analyzing the data, writing the course grid, writing the first draft, getting the experts' judgement, revising the worksheet and writing the final draft. The subject of this research were 42 students of grade X Senior High School Teladan Medan. There were two questionnaires employed ${ }^{1}$ in this research: (1) need analysis questionnaire which distributed to the students and (2) worksheet evaluation questionnaire which distributed to the worksheet experts to evaluate the speaking worksheet. The data obtained from the need analysis questionnaire were analyzed using frequency and percentage, while the data from evaluation questionnaire were analyzed using descriptive statistic. This research developed six units of speaking worksheet. The speaking worksheet for grade X students of Senior High School Teladan Medan consists of Observing, Questioning, Exploring, Associating and Communicating stages. Based on the experts' judgement of the content, the language, the presentation and the graphic, the develop speaking worksheet is appropriate to be used for grade X students' of Senior High School Teladan Medan. The mean score of all aspects was 4.68 and chategorized as "very good" since the range was in interval 4.5. $<\mathrm{X} \leq 5$.
\end{abstract}

Keywords : Research and Development $(R \& D)$, Speaking Worksheet, Scientific Approach

*Graduate Status

***Lecturer Status 


\section{INTRODUCTION}

\section{Background of Study}

Speaking is one of the productive skill of four main skills of language. It is taught broadly in elementary school up to university. Speaking as a productive skill is much needed for students tobe mastered because students always need language to communicate in daily activity. It is also supported by the role of English as an International language which underlines the importance of English speaking ability. By having a good ability in speaking, students would be easily express their feelings, thought and ideas in social interactions. The important of having a good skill in speaking is also in line with the purpose of English learning in senior high school where based on education ministry poloci (permendikbud) no 59 year 2014 about the 2013 curriculum, the purpose of English learning in senior high school is to develop students' communicative competence in spoken and written language of interpersonal, transactional and functional texts.

English is one of the subject in senior high school that covers four skills have to be mastered by students in accordance with the goal of learning. Those skills are listening and reading as the receptive skills and speaking and writing as productive skill. Listening and reading are grouped under the term receptive skill because the learners use these skill for receiving information while speaking and writing used for producing and conveying information.

As the essential subject that students need to be mastered and considering that English is not the first or second language in Indonesia which means students are not accustomed to use this language in their daily life communication, teachers need to pay more attention to teach speaking because learning this language is 
more difficult to English non-native speaker like Indonesia students. It's also in line with Nunan (2003:48) who states that speaking in a new language is harder than reading, writing or listening.

In order to overcome the problem above, teachers should provide an appropriate speaking material because material is a tool that used by both teacher and learner to stimulate and guide the process of teaching and learning. Material is one of many factors that effect how fast the students develop their mastery in learning. There are many types of material that can be used by teachers in teaching and learning process. They can be in printed form such as textbook, workbook, worksheet, etc or in audio and video form. In this research, the researcher planned to develop the worksheet especially for speaking skill.

In order to find out the problem existed in speaking material used in Senior High School, the researcher tried to get the material which was used by grade X of senior high school Teladan Medan. The English teacher used Pathway to English book published by Erlangga in teaching and learning process. The Pathway English book was based on the curriculum 2013. The content of Pathway book had been organized under five steps of scientific approach; observing, questioning, exploring, associating and communicating. In addition, the book consisted of some pictures, texts, exercises which were used by the students to facilitate the learning activities.

The first problem of the book occured within the exercises or text of the book, the material was not in line with the basic competence which the students were expected to be able to apply or use the social function, the generic stucture, 
languange features and final contruct the spoken text of complimenting and make written and oral text to express and respond complementing and care. The fact was some exercises in the book did not relevant to the basic competence, it also did not covered the speaking area there are three things; mechanics (pronounciation, grammar and vocabulary), functions (transaction and interaction) and social and cultural rules and norm (turn taking, rate of speech, length of pause between speakers, relative roles of participants)

To increase students' speaking skill ability, learning effiency, learning interest, and to make students easier communicating using English, the researcher tried to develop develop English speaking worksheet especially for the first semester of grade X students of Senior High School Teladan Medan. And it was expected that the speaking worksheet could improve the students' speaking ability.

\section{CONCEPTUAL FRAMEWORK}

The importance of English recently, the mastery of speaking need to be rocognized remebering speaking is one of basic skills of English language. To help the students to be mastered in speaking skill, the tecaher should use the appropriate teaching materials because teaching materials are the most importance in language teaching that will lead teacher and students in teaching and learning process. One of the teaching materials that can be used by the teacher is worksheet because it has extra exercises that facilitate the students to achieve the learning objectives.

Scientific approach was used to develop the worksheet for grade tenth senior high school students. It was choosen because scientific approach would 
give positive contributions to the students' participation and critical thinking as the researchers previous proven where scientific approach is the learning method which highlights the personal experiences through five stages; observing, questioning, exploring, associating and communicating. To get the relevant speaking worksheet, the reseracher used the procedure of educational reserach and develpment by Borg and Gall (2003).

The worksheet was developed using scientific approach stages. It meant in developing this worksheet, the researcher developed the task or activities based on the five stages of scientific approach; observing, questioning, experimenting, associating and communicating. Observation is the first stage in scientific approach. In this stage, the students would do some activities such as reading, listening, looking (with or without media), the second stage is questioning. In this stage, the students can give or answer some questions that are factual related to the observation, In experimenting stage, the students will do some activities such as doing experiment, reading other sources, observing other object or activity, ect. In associating stage, the students can classify data that they get from several sources and associate some events to become memory in their thoughts. In the last stage of scientific approach, the students will convey the information or conclusion they got based on their analysis orally and written. Finally, the researcher was done in addition to produce the appropriate speaking worksheet for grade tenth students of Senior High School Teladan Medan. 


\section{RESEARCH METHODOLOGY}

This research was conducted by applying Research and Development (R\&D) research by Borg and Gall (2003) in fulfilling the students' need in speaking worksheet.

This research was conducted by following steps:

1. Gathering data/ information

2. Analyzing the data

3. Designing the course grid

4. Designing the Speaking worksheet

5. Evaluating/validating the materials by expert

6. Revising the worksheet

7. Final product.

The writer chose this model of development because it had some stages which were clear and appropriate with procedure.

The research place was at Senior High School Teladan Medan with 42 students of X ISOS 2. The source of data was syllabus, existing materials, teachers' interview and students' questionnaires as qualitative data. The data questionnaires and interview was the instruments of research that analyze descriptively.

\section{Techniques of Analyzing Data}

In collecting the data the researcher used questionnaires, observation and interview. The first, the writer observed the syllabus and material, analyze the basic competence and the book. The second, the researcher did interview section to the English teacher who taught in the tenth grade students Senior High School 
Teladan Medan. The researcher also did obeservation when teaching and laerning process was running. It had function to get information about students, problem which was faced in learning English especially speaking, and also about the materials.

The third, the researcher gave the questionnaires to the students in order to get information about students' need in learning English. In this section the researcher shared the questionnaire. So, the researcher can get information toward students' need, problem in learning English and their interest in speaking.

The flow chart of developing the speaking worksheet

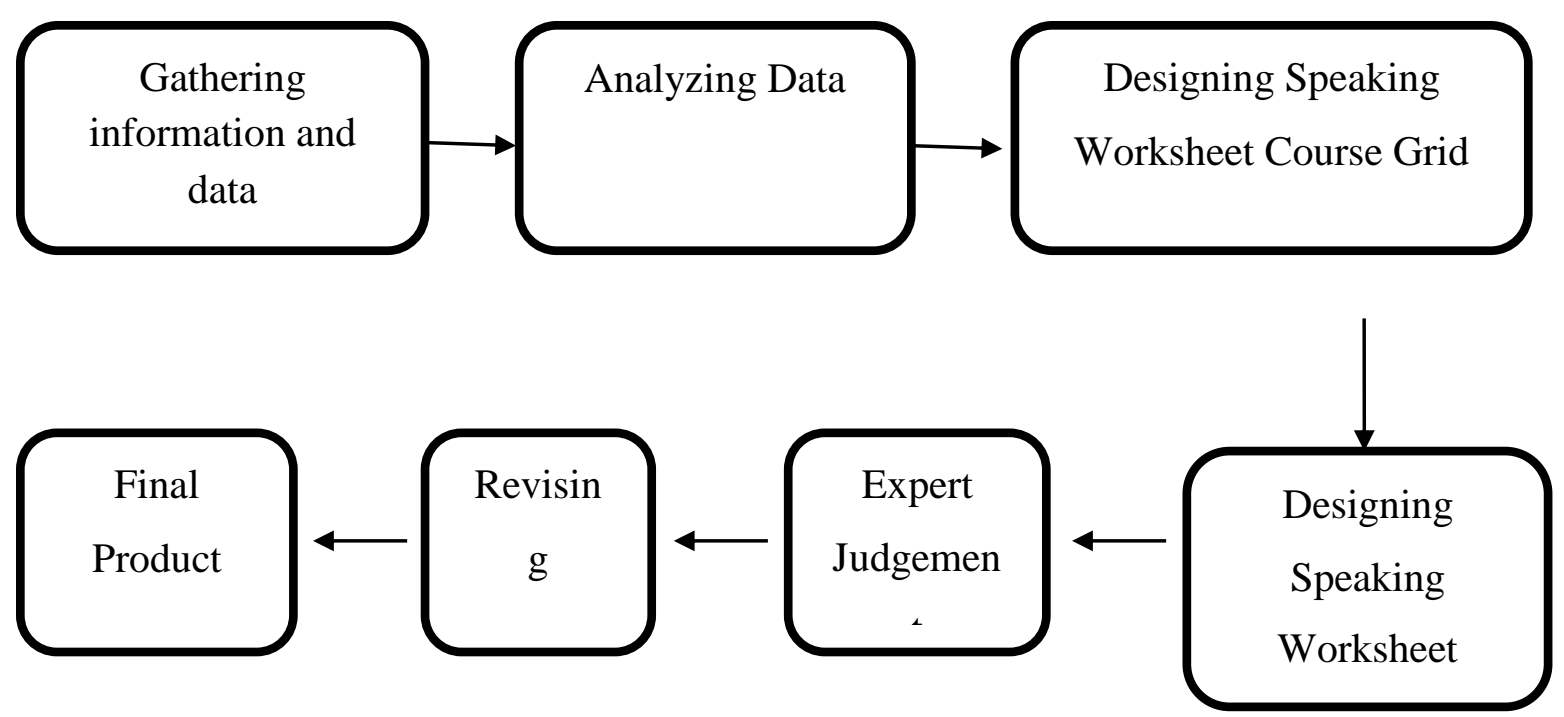

Figure 1.The flow chart of developing speaking worksheet

\section{RESEARCH FINDINGS AND DISCUSSION}

\section{Result Of need analysis}

\section{The Description of the Need Analysis}

The analysis of target needs was viewed at three aspects, namely necessities, lacks, and wants. The result of need analysis showed that in term of shor-term goal, the students need speaking skill in English to be able to do the learning 
activities effectively in class, while in term of long-term goal the students need English to continue their study abroad and postgraduate. In addition to the goal, the students expected that learning English speaking can help them are to be able to master grammar and apply them in oral communication in the classroom and to help them to be able to master vocabulary in order to understand spoken and written text and use them in oral communication. Therefore, this researh developed the English speaking worksheet for them in term of academic purposes.

In term of speaking elements, the students chose a wide range of vocabulary and clear pnonounciation as the most needed speaking elements in learning.

In term of lack, the students felt a little bit difficult to understand when somebody talks to me in English by using various topics, the students had difficulty to find the appropriate words for the sentences that they are going to say and applying grammar to the sentences.

In term of wants, the students wanted that English learning process can help them to be able to speak English more fluently.

\section{The Description of Learning Need}

The students learning needs were found in the items which are categorized as input, procedure and setting. In term of input, the students wanted to have short monologue, dialogue and pictures as the input so that the input given were in the form of conversation, short monologue text and pictures. Moreover, the topic that the students wanted to discuss in the units are about education life and daily activity. Therefore, in the implementation, those topics are used in units of 
developed worksheet. Students' preference regarding the learning procedure is summarized as follow.

The students preferred to do speaking activities like analyzing the dialogue and role play. Instead of the main learning activities for speaking, in the worksheet, the students would be provided with activities which aim to enrich their vocabulary mastery, grammar and pronounciation. Regarding to the learning activity to study vocabulary, the students preferred to do activities like matching the words with the provided defenition and identifying the part of speech (noun, adjective, verb, etc.). While in learning grammar, students choose activities Completing paragraph with grammatically correct sentences and creating sentences using the learned pattern of grammar. Finally, in learning pronounciation, the students wanted pronouncing words that have been given pronounciation transcription and repeating the teacher/tutor's pronounciation loudly.

In term of setting, it was found out that the students needs are the role of learners and teachers in process of learning. The result of the need analysis in term of learners' role are summarized as follow. In carring out the activity, the students wanted to listen the tutor/teachers' explanation and take a note, participate actively in the discussion activity and share opinion with the tutor and their classmate about the particular topics. Regarding to the teachers' role, the students preferred to have tutor/teachers as resourcer (the tutor acts as knowledge and information sources who gives you example before you practice the task). 


\section{The result of Interview}

From the interview section, most of students cannot speak English fluently, because they lack of vocabulary and they did not have self confidence and could not used grammar well when they wre going to speak. It has an impact on students' interest; some of them were not interested to learn English.

\section{Developing Speaking Worksheet}

The data was analyzed based on target needs analysis (Necessities, lack, and want) and learning needs (input, procedure, and setting). The developing speaking worksheet developed based on scientific approach. It has five stages in scientific approach; observing, questioning, experimenting, associating and communicating.

\section{The Expert's Validation}

The two materials were examined by the two experts and the following tables are the result of experts' judgment.

Table1.the English Lecturer Validation Scores

\begin{tabular}{llccc}
\hline No. & \multicolumn{1}{c}{ Criteria } & $\begin{array}{c}\text { The Number } \\
\text { Of Criteria }\end{array}$ & $\begin{array}{c}\text { Maximum } \\
\text { Score }\end{array}$ & Score \\
\hline 1. & $\begin{array}{l}\text { The Appropriateness of the } \\
\text { content }\end{array}$ & 8 & 40 & 39 \\
\hline $2 . \quad \begin{array}{l}\text { The Appropriateness of the } \\
\text { language }\end{array}$ & 7 & 35 & 31 \\
\hline 3. & $\begin{array}{l}\text { The Appropriateness of the } \\
\text { presentation }\end{array}$ & 4 & 20 & 18 \\
\hline The Appropriateness of & 6 & 30 & 27 \\
\hline & Layout
\end{tabular}

$$
\text { Average }=\frac{115}{25}=4.6 \text { or in percentage }=\frac{115}{125} \times 100 \%=92 \%
$$


Table 1.2 the English Teacher Validation Scores

\begin{tabular}{|c|c|c|c|c|}
\hline No. & Criteria & $\begin{array}{l}\text { The Number } \\
\text { Of Criteria }\end{array}$ & $\begin{array}{l}\text { Maximum } \\
\text { Score }\end{array}$ & Score \\
\hline 1. & $\begin{array}{l}\text { The Appropriateness of } \\
\text { Linguistic }\end{array}$ & 8 & 40 & 39 \\
\hline 2. & $\begin{array}{l}\text { The Appropriateness of } \\
\text { Process }\end{array}$ & 7 & 35 & 34 \\
\hline 3. & $\begin{array}{l}\text { The Appropriateness of } \\
\text { Product and Content }\end{array}$ & 4 & 20 & 20 \\
\hline \multirow[t]{2}{*}{4.} & $\begin{array}{l}\text { The Appropriateness of } \\
\text { Layout }\end{array}$ & 6 & 30 & 29 \\
\hline & & 25 & 125 & 122 \\
\hline
\end{tabular}

The average from English Lecturer and English Teacher can be seen in the below.

$$
\text { Average }=\frac{4.6+4.88}{2}=4.68 \text { or in percentage } \frac{92 \%+97,6 \%}{2}=94,8 \%
$$

The average from English Lecturer and English Teacher are categorized as "very good"

\section{CONCLUSIONS AND SUGGESTIONS}

\section{A. Conclusions}

Based on the need analysis from the questionnaire and the interview, it is concluded that the students of grade X Senior High School Teladan Medan need the appropriate English speaking worksheet. The English speaking worksheet was developed in order to increase their ability in speaking. 
The English speaking worksheet was developed by using sseven phases of Research and Development (R \& D), they were; 1) gathering information and data, 2) analyzing data, 3) designing speaking worksheet course grid, 4) designing the speaking worksheet, 5) expert judgement, 6) revising the worksheet, 7) final product. The worksheet was arranged under the five stages of Scientific Approach; observing, questioning, exploring/experimenting, associtaing and communicating. And the develop worksheet based on Scientific Approach was appropriate to be used by grade X students of Senior High School Teladan Medan.

\section{B. Suggestions}

In line with the conclusion above, some suggestions are given as follows:

\section{Students}

The grade $\mathrm{X}$ of Senior High School should create a communicative circumtance in English classroom by being involved actively in learning activities.. They also need to do the tasks earnestly to improve their own speaking skill. The students also can find the others material related to their study from internet or the other book if the existing material has not been appropriate with their needs.

\section{English Teachers}

English teacher is one of important points to make tecahing and learning process become successful. To achieve the goal of the study, the teacher should understand well the students' needs in learning English and also the teacher should be more creative to encourage and motivate the students speak using the provided worksheet. The teacher is suggested to add more sources to enhance the 
students' speaking skill. The teacher also should be perceptive with the practice and materials given whether they are useful in helping the students to increase their speaking skill or not.

\section{Other Worksheet Developers}

To other worksheet developers, they can develop English materials for Senior High School students for other skill such as writing, reading, listening or materials with integrated four skills. And this research can be references for the other developer. 


\section{REFERENCES}

Brown, H. Douglas. 2001. Teaching by Principles: An Interactive Approach to Language Pedagogy. New York: Pearson Education.

Gall, M.D., Gall, J.P.,\& Borg, W.R. 2003. Educational Research: An Introduction. 7th Edition. Boston: Pearson Education.

Graves, K. 2000. Designing Language Courses: A Guide for Teacher. New York: Heinle\&Heinle.

Morrison, G. R., Ross, S.M., \& Kemp, J. E. (2007). Designing Effective Intruction (5th). Hoboken, NJ:Jonh Wiley\& Sons, Inc.

Nichols Hess, A., K. (2016). Designing for Engagement: Using the ADDIE Model to Integrate High-Impact Practices into an Online Information Literacy Course. Communication in Information Literacy Journal. Vol. 10, no. 2. Oakland University.

Nimasari, E. P. "English Materials Development Based on Scientific Approach : A Content Analysis of "When English Rings A Bell" Course Book. Muhammadiyah University Ponorgo

Nuna, D. (2001).Designing Task for the Communicative Classroom. Cambridge: Cambridge University Press

Rahma S. 2017. Developing English Speaking Materials Based on Task-Based Learning for Grade X students of Marketing Study Program at SMK Negeri 1 Medan. A Thesis. State University of Medan.

Richards, Jack. 2008. Teaching Listening and Speaking: From Theory to Practice. Cambridge: Cambridge University Press

Shofwan, Imam. 2016. "The Use of Scientific Approach in Teaching English as a Foreign Language in SMP N 1 Jakarta”. Semarang. Semarang University

Majid, A. 2008. Perencanaan Pembelajaran Mengembangkan Standart Kompetensi Guru. Bandung: Rosda Karya 